\title{
Changes in the snow water equivalent in mountainous basins in Slovakia over recent decades
}

\author{
K. Hlavčová, K. Kotríková, S. Kohnová, and P. Valent \\ Department of Land and Water Resources Management, Faculty of Civil Engineering, Slovak University of \\ Technology in Bratislava, Bratislava, Slovakia \\ Correspondence to: K. Hlavčová (kamila.hlavcova@stuba.sk)
}

Received: 11 March 2015 - Accepted: 11 March 2015 - Published: 11 June 2015

\begin{abstract}
Changes in snowpack and duration of snow cover can cause changes in the regime of snow and rainsnow induced floods. The recent IPCC report suggests that, in snow-dominated regions such as the Alps, the Carpathian Mountains and the northern parts of Europe, spring snowmelt floods may occur earlier in a future climate because of warmer winters, and flood hazards may increase during wetter and warmer winters, with more frequent rain and less frequent snowfall. The monitoring and modelling of snow accumulation and snow melting in mountainous catchments is rather complicated, especially due to the high spatial variability of snow characteristics and the limited availability of terrestrial hydrological data. An evaluation of changes in the snow water equivalent (SWE) during the period of 1961-2010 in the Upper Hron river basin, which is representative of the mountainous regions in Central Slovakia, is provided in this paper. An analysis of the snow cover was performed using simulated values of the snow water equivalent by a conceptual semi-distributed hydrological rainfall-runoff model. Due to the poor availability of the measured snow water equivalent data, the analysis was performed using its simulated values. Modelling of the SWE was performed in different altitude zones by a conceptual semi-distributed hydrological rainfall-runoff model. The evaluation of the results over the past five decades indicates a decrease in the simulated snow water equivalent and the snow duration in each altitude zone and in all months of the winter season. Significant decreasing trends were found for December, January and February, especially in the highest altitude zone.
\end{abstract}

\section{Introduction}

A snowpack as natural water storage is a very important part of the hydrological balance in mountainous catchments. As a result of conditions caused by a changing climate, the temporal and spatial changes of snowpacks is the subject of many recent studies (e.g., Artan et al., 2013; Holko et al., 2005, 2011; Hood and Hayashi, 2010; Kuchment et al., 2010; Parajka and Blöschl, 2008; Parajka et al., 2012). Analyses of flood changes in Europe (Hall at al., 2014) also indicate changes in spring floods which can be caused by changes in the snow regime especially in snow-dominated regions.

In Slovakia, snow cover data have been collected since the middle of the 20th century. Due to the poor availability of snow water equivalent data, many studies that aim at detecting changes in snow packs in Slovakia have been based on an analysis of point measurements of snow depths and the duration of snow cover (e.g., Lapin and Faško, 2005, 2007) rather than on the snow water equivalent (SWE). However, the snow water equivalent evaluated on a catchment scale can provide more complete information about the amount of water contained in snow and is more useful than interpolated snow cover or snow depths for flood prediction and the management of water resources in snow-dominated regions. In this paper we evaluated the changes in the snow water equivalent in a mountainous basin in Slovakia using the modelled values of the SWE during the period of 19612010. The SWE in different altitude zones of the pilot basin was simulated using a semi-distributed conceptual rainfallrunoff model at a daily time step. The validation of the simulated SWE values was provided by comparing them with the available measured data of the snow water equivalent in each altitude zone. The changes in the simulated values of 
Table 1. List of the altitude zones.

\begin{tabular}{lrrrr}
\hline & $\begin{array}{r}\text { area } \\
\text { dimensions [ha] }\end{array}$ & weight & $\begin{array}{r}\text { zonal } \\
\text { boundaries [m a.s.1.] }\end{array}$ & $\begin{array}{r}\text { the mean } \\
\text { altitude [m a.s.1.] }\end{array}$ \\
\hline altitude zone 1 & 38004 & 0.22 & $260-616$ & 438 \\
altitude zone 2 & 90616 & 0.51 & $617-972$ & 794 \\
altitude zone 3 & 37348 & 0.21 & $973-1328$ & 1150 \\
altitude zone 4 & 9268 & 0.05 & $1329-1684$ & 1506 \\
altitude zone 5 & 1628 & 0.01 & $1685-2040$ & 1862 \\
\hline
\end{tabular}

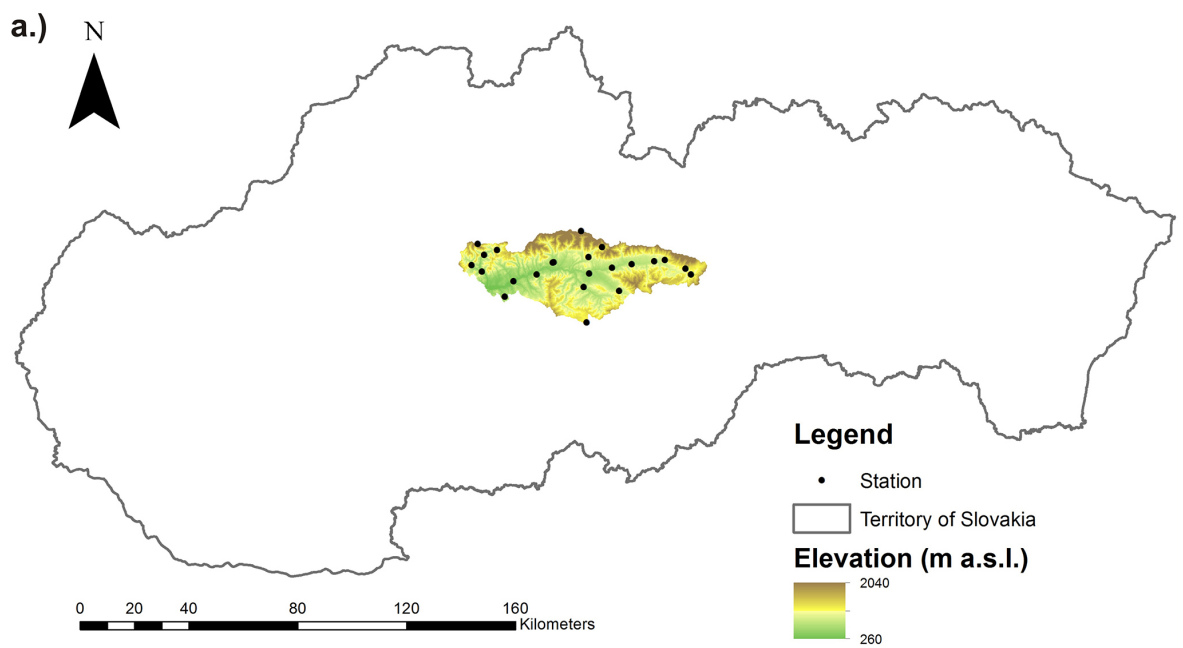

b.)

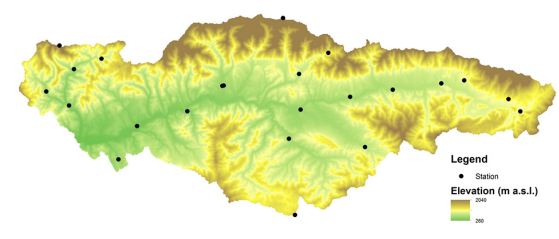

c.)

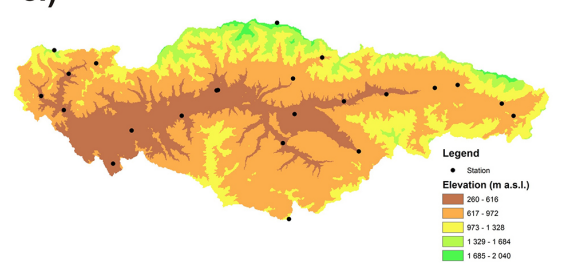

Figure 1. The upper Hron River basin indicating (a) the catchment location in the territory of Slovakia, (b) the elevations of the catchment and precipitation stations, (c) the altitude zones of the catchment).

the SWE were evaluated for each decade from 1961-2010 and in each altitude zone.

\section{The Hron rainfall-runoff model}

The Hron model is a rainfall-runoff model based on the concept of the HBV model (Bergström, 1992) and was developed at the Department of Land and Water Resources Management of the Faculty of Civil Engineering of the Slovak University of Technology in Bratislava, Slovakia. This is a conceptual model with lumped parameters, which divides a river basin into nonlinear reservoirs. The model works at a daily time step and has three sub-models, i.e., a snow submodel for the simulation of snow accumulation and melting, a soil sub-model that simulates the amount of water in soil and the actual evapotranspiration, and a runoff sub-model that simulates the routing of runoff within the river basin and along the river reach.

The model is processed in Matlab, and there are several innovations and differences in comparison with the original HBV concept (Valent et al., 2011), e.g., the runoff routing is based on a multilinear cascade (Szolgay et al., 2008). The model was adapted for the simulation of snow water equivalent at different altitude zones with semi-distributed parameters. The calibration of the model parameters is based on genetic algorithms or a harmonic search as well as on several objective functions for assessing the reliability of the model calibration. The simulated output states at every time step are characterized by lumped variables, i.e., the water level in the upper storage $[\mathrm{mm}]$; the water level in the lower storage $[\mathrm{mm}]$; and the distributed states are divided according to the altitude zones: the values of soil moisture [mm], the actual 

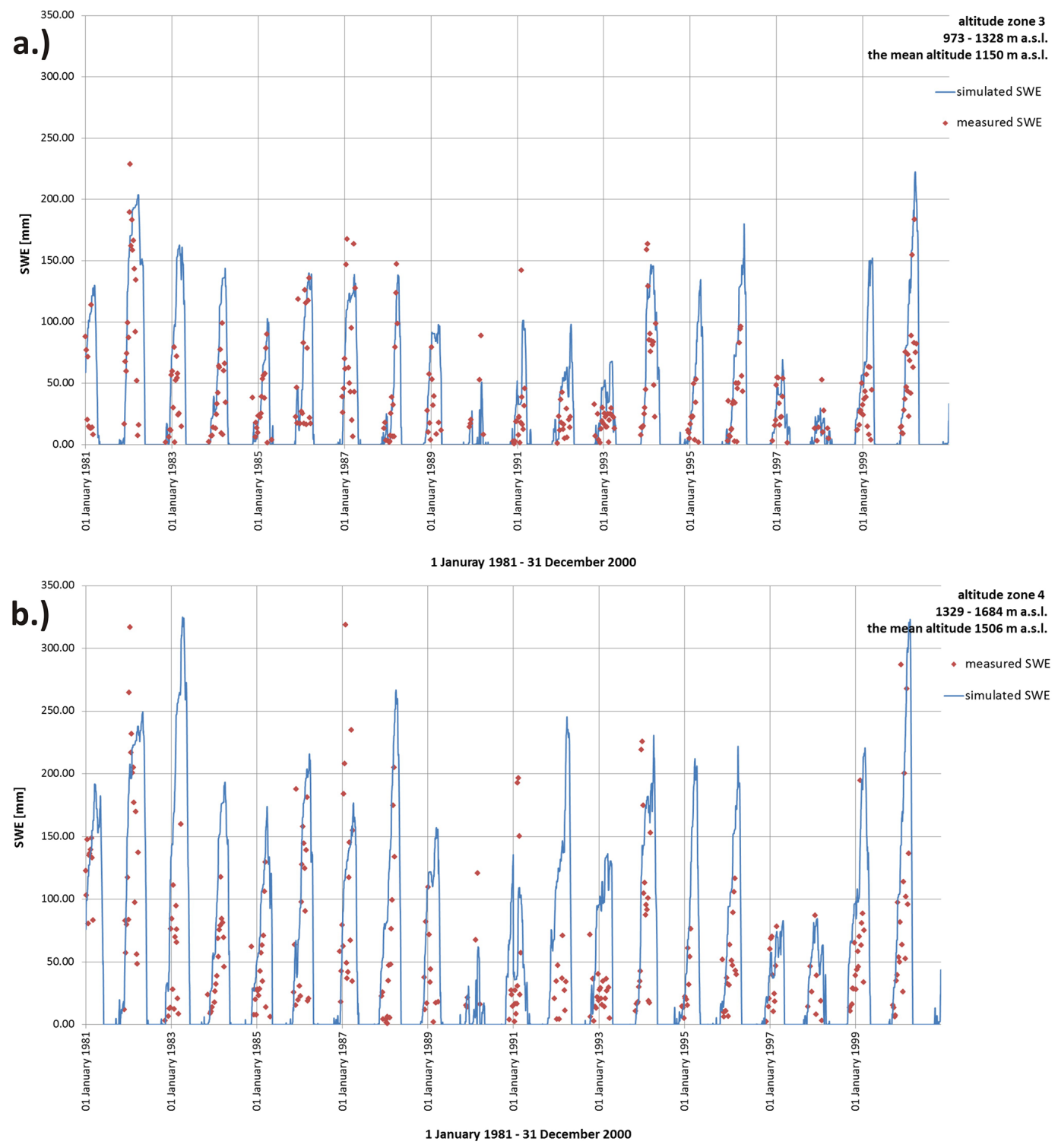

Figure 2. Comparison of simulated and measured SWE in (a) the third and (b) the fourth altitude zones of the Upper Hron during the period of 1981-2000.

evapotranspiration $\left[\mathrm{mm} \mathrm{day}^{-1}\right]$, and the snow water equivalent $[\mathrm{mm}]$.

\section{The input data}

The upper Hron River basin with available measured snow data at 23 precipitation stations was selected as the pilot basin (Fig. 1a, b). The Hron River is the second longest river in Slovakia with a length of $298 \mathrm{~km}$. The upper part of the Hron River basin with an outlet in Banská Bystrica, which is located in Central Slovakia, has a mountainous character, and its area is $1766.48 \mathrm{~km}^{2}$. The catchment belongs to a cold and wet climate region; it has a snow-rain runoff regime
(Pekárová and Szolgay, 2005). During the period of 19612000 the prevailing floods in the upper Hron River basin were induced by long-rain and rain on snow processes (Holko et al., 2005).

The input data used for the modelling of the snow water equivalent for the period of 1961-2010 were divided into different altitude zones (Table 1, Fig. 1c). For each zone, daily rainfall was estimated by the inverse distance weighting interpolation; the zones' average air temperature values were calculated by linear regression between the stations' mean daily air temperatures and the altitudes of the stations. The daily evapotranspiration values were calculated by the Blaney-Criddle method (Parajka et al., 2003). The calcula- 


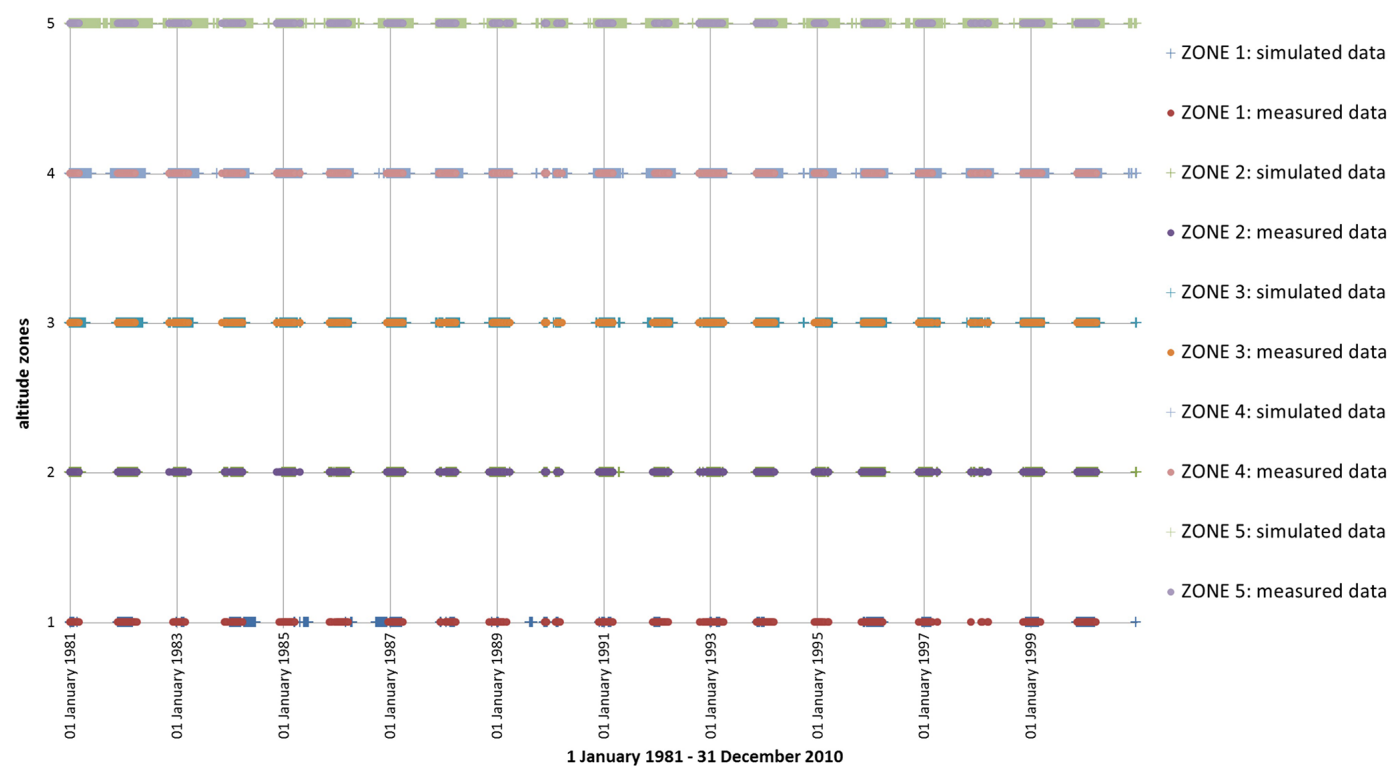

Figure 3. Comparison of simulated and measured snow cover duration in all zones of the Upper Hron during the period of 1981-2000. Circles show measured presence of snow cover, plusses show simulated presence of snow cover.

tions were based on the basin's average daily air temperature and the sunshine index of the river basin.

Mean daily discharge at the basin outlet for the period of 1961-2010 was used for calibrating the model parameters. The measured values of the snow water equivalent which were used for the validation of the simulated SWE were available at 23 precipitation stations (measured once a week on Monday) from the period of 1981-2000.

\section{Results}

The parameters of the Hron rainfall-runoff model were calibrated using the method of genetic algorithms, with the aim of achieving the best agreement between the observed and modelled mean daily discharges at the basin outlet. Several approaches for selecting the calibration periods were tested (Kotríková et al., 2013). In this paper the parameters were calibrated during the period of 1961-1990 and validated during the period of 1991-2010. The choice of the calibration and validation periods was based on two factors. In the WMO Guide No. 100 (2011), the period of 1961-1990 is recommended as a reference period for climate change impact studies. Also, an analysis of the air temperatures of the Hron River basin showed that the years of 1961-1990 can represent a cooler period and the years of 1991-2010 a warmer one. The Nash-Sutcliffe coefficient of $0.8405 \mathrm{ob}-$ tained for the calibration period and 0.8011 for the validation period confirmed the applicability of the model parameters for modelling in the upper Hron River basin over the last few decades.
The correctness of the simulated values of the snow water equivalent was verified by comparing them with the weekly measured data of the SWE in each altitude zone for the period of 1981-2000. We compared the simulated daily values averaged over each zone with the measured values of the SWE for the mean altitude of each zone. The measured values of the SWE for the mean altitude of each zone were calculated from the measured SWE values at the rain gauge stations by linear regression. A visual comparison of the SWE shown in Fig. 2 (third and fourth altitude zones) and snow duration (Fig. 3) indicates a satisfactory degree of agreement between the daily simulated and weekly measured SWE values. Some differences could be caused by a problematic estimating basin averages from the measured SWE data related to missing data at some rain gauge stations and windward and leeward effects caused by the complexity of the terrain.

The changes in the simulated SWE were evaluated by comparing the mean, minimum and maximum daily values of the SWE on each calendar day of the decades of 19611970, 1971-1980, 1981-1990, 1991-2000, and 2001-2010 in each altitude zone. As examples, we show a comparison of the mean daily values of SWE in each decade for the third and fourth altitude zones in Fig. 4; and a comparison of the mean daily values of the SWE in the decades of 1961-1971 and 2001-2010 for each altitude zone (Fig. 5a, b).

As can be seen in Figs. 4 and 5, there is a decreasing tendency in the simulated SWE and a reduction in the snow cover duration in recent decades. In the first and the second altitude zones the snow cover started in early November and ended by mid-April in the first decade, after 40 years the snow cover starts at the end of October and ends at the end of April. In the third altitude zone the snow cover occurred 

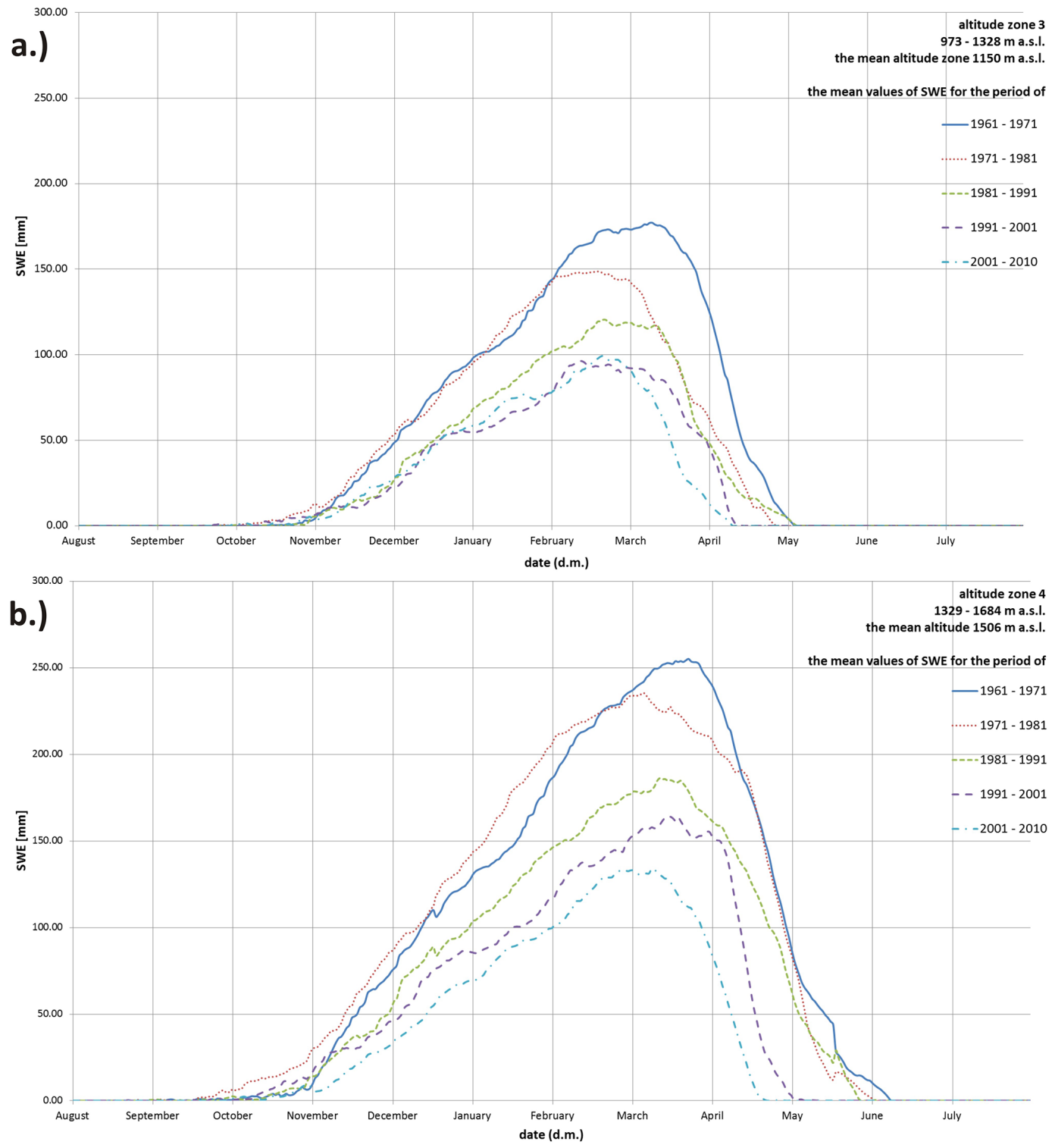

Figure 4. Simulated mean daily SWE for each decade in (a) the third and (b) the fourth altitude zones of the Upper Hron.

from early October to the second half of May in the period of 1961-1971, but in the last period of 2000-2010 the end of snow cover had moved to the end of April. The reduction of the snow cover duration is more clearly visible in the fourth altitude zone; in the first decade the snow cover started in the second half of September and ended at the end of June. In the last decade the snow cover started in early October and ended in early May. In the earliest decade, snow was present throughout the year in the highest altitude zone, but in the last decades snow occurred only from the end of August to mid-June, and more than a month now is without snow cover in altitude zone 5 .

The decreasing trends of simulated SWE in all altitude zones were confirmed in the previous research of the au- thors by a non-parametric Mann-Kendall test (Kotríková and Hlavčová, 2014). The significance of the trends was tested at the $95 \%$ level of significance and it is shown in Table 2.

\section{Conclusions}

The objective of this paper is an evaluation of changes in the simulated snow water equivalent in the last 50 years for different altitude zones of a selected mountainous catchment in Slovakia. Modelling of the snow water equivalent was performed using a semi-distributed hydrological rainfall-runoff model known as Hron, which was adapted for modelling the different altitude zones. The Hron model provides more detailed output data than its lumped version, which con- 

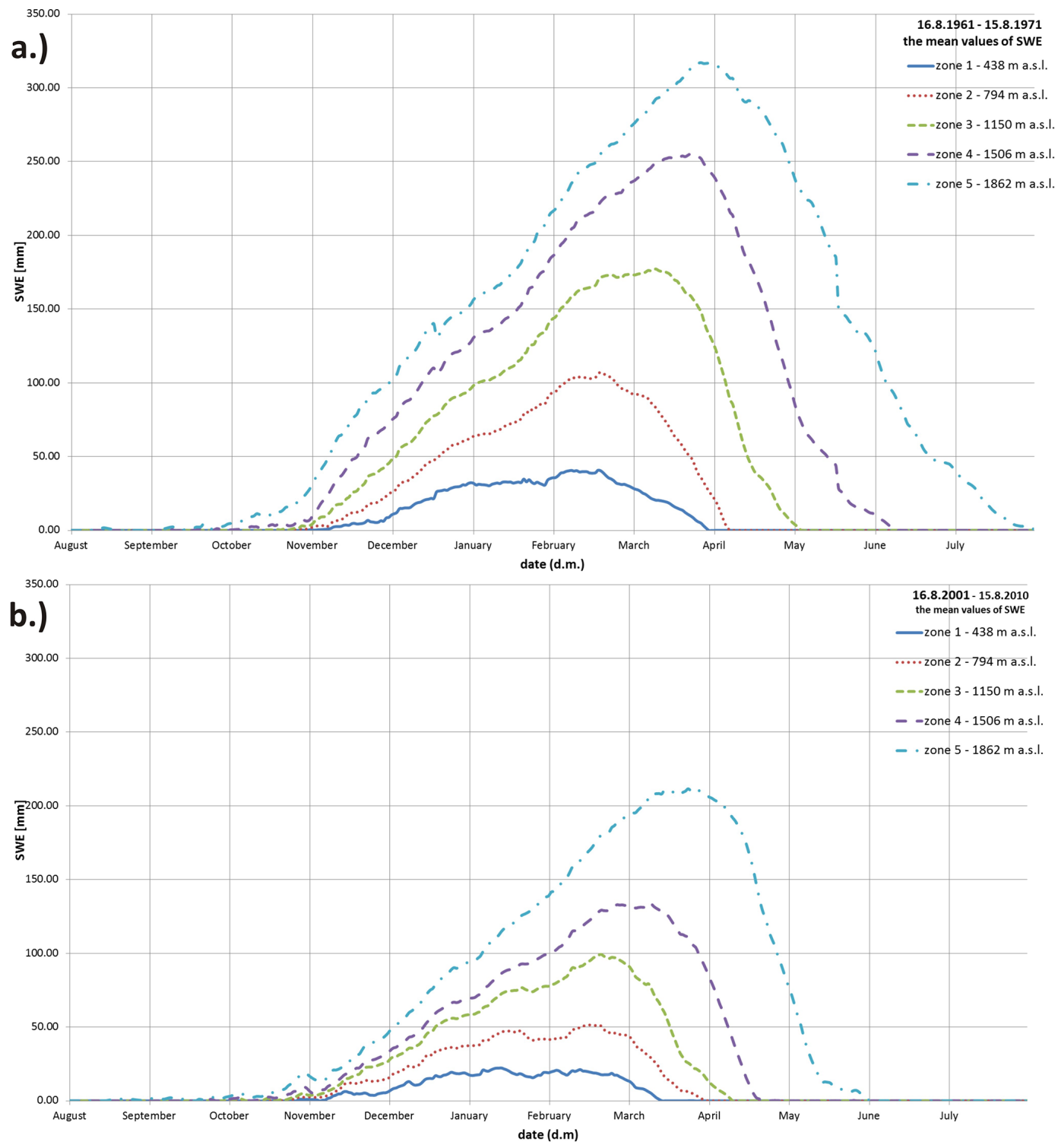

Figure 5. Simulated mean daily SWE for the decades of (a) 1961-1971 and (b) 2001-2010 in each altitude zone of the Upper Hron.

tributes to increasing the level of accuracy of the modelling of snow accumulation and snow melting in mountainous basins (Kotríková and Hlavčová, 2014).

The upper Hron River basin was divided into five altitude zones. The parameters of the model were calibrated for the period of 1961-1990 and validated for the last 20 years. The robustness of the simulated values of snow water equivalent was verified by comparing them with the weekly measured data of SWE at each altitude zone for the period of 1981-2000. The comparison indicates a satisfactory degree of agreement between the simulated SWE in each altitude zone and the measured SWE. The results suggest a decreasing tendency in the simulated snow water equivalent in the upper Hron River basin during the period of 1961-2010 in all the months of the winter season (from November to April), which confirmed the results of the authors' previous research. The modelled outcomes also revealed a significant decrease in the SWE in some months of the summer season (from May to July), especially in the higher altitude zones.

The results also show a reduction in the snow cover duration, especially in the higher altitude zones. This reduction could be caused by the increasing air temperatures and changes in precipitation in recent decades. The shift of date of the ending of the snow cover towards the winter months may indicate an earlier occurrence of spring snowmelt floods in this region. This may imply that flood risk may increase during warmer winter seasons with more frequent floods induced by rain-on-snow processes. 
Table 2. The significance of decreasing trends of the simulated SWE in all altitude zones.

\begin{tabular}{lccccc}
\hline & altitude zone 1 & altitude zone 2 & altitude zone 3 & altitude zone 4 & altitude zone 5 \\
\hline January & no & no & yes & yes & yes \\
February & no & yes & yes & yes & yes \\
March & no & yes & yes & yes & yes \\
April & no & yes & yes & yes & yes \\
May & no & no & yes & yes & yes \\
June & no & no & no & no & yes \\
July & no & no & no & no & yes \\
August & no & no & no & no & no \\
September & no & no & no & no & no \\
October & no & no & no & no & no \\
November & no & no & no & yes & no \\
December & no & no & yes & yes & yes \\
\hline
\end{tabular}

Acknowledgements. This work was supported by the Slovak Research and Development Agency under Contract No. APVV-030311 and VEGA grant 1/0776/13.

\section{References}

Artan, G. A., Verdin, J. P., and Lietzow, R.: Large scale snow water equivalent status monitoring: comparison of different snow water products in the upper Colorado Basin, Hydrol. Earth Syst. Sci., 17, 5127-5139, doi:10.5194/hess-17-5127-2013, 2013.

Bergström, S.: The HBV model - its structure and applications, SMHI Reports RH, No. 4, Norrköping, 1992.

Guide to Climatological Practices, WMO-No.100, ISBN 978-9263-10100-6, 117 pp., WMO, Geneva, 2011.

Hall, J., Arheimer, B., Borga, M., Brázdil, R., Claps, P., Kiss, A., Kjeldsen, T. R., Kriaučiūniene., J., Kundzewicz, Z. W., Lang, M., Llasat, M. C., Macdonald, N., McIntyre, N., Mediero, L., Merz, B., Merz, R., Molnar, P., Montanari, A., Neuhold, C., Parajka, J., Perdigão, R. A. P., Plavcová, L., Rogger, M., Salinas, J. L., Sauquet, E., Schär, C., Szolgay, J., Viglione, A., and Blöschl, G.: Understanding flood regime changes in Europe: a state-of-the-art assessment, Hydrol. Earth Syst. Sci., 18, 27352772, doi:10.5194/hess-18-2735-2014, 2014.

Holko, L., Kostka, Z., and Pecušová, Z.: Snow, in: Scenarios of changes in selected components of the hydrosphere and biosphere in the Hron River Basin and the balance due to climate change, edited by: Pekárová, P. and Szolgay, J., Veda Bratislava, Slovakia, 105-167, 2005 (in Slovak).

Holko, L., Gorbachova, L., and Kostka, Z.: Snow Hydrology in Central Europe, Geography Compass, 5, 200-218, doi:10.1111/j.1749-8198.2011.00412.x, 2011.

Hood, J. L. and Hayashi, M.: Assessing the application of a laser rangefinder for determining snow depth in inaccessible alpine terrain, Hydrol. Earth Syst. Sci., 14, 901-910, doi:10.5194/hess14-901-2010, 2010.

Kotríková, K., Hlavčová, K., Szász, V., and Papinčáková, L.: Estimation of changes in snow storage in mountainous basins in Slovakia, HydroCarpath 2013. Catchment processes in regional hydrology: Experiments, Modeling and Predictions in Carpathian
Drainage Basins: Proceedings, International conference, Sopron, Hungary, 27-28 October 2013, 2013.

Kotríková, K. and Hlavčová, K.: Estimation of the simulated snow water equivalent for different altitude zones in a mountainous basin in Slovakia, HydroCarpath Catchment Processes in Regional Hydrology: Confronting experiments and modeling in Carpathian drainage basins, ISBN 978-963-359-036-2, Sopron, University of West Hungary Press, 2014.

Kuchment, L. S., Romanov, P., Gelfan, A. N., and Demidov, V. N.: Use of satellite-derived data for characterization of snow cover and simulation of snowmelt runoff through a distributed physically based model of runoff generation, Hydrol. Earth Syst. Sci., 14, 339-350, doi:10.5194/hess-14-339-2010, 2010.

Lapin, M. and Faško, P.: Snow cover changes in the Little Carpathians in Slovakia, Croatian Meteorological Journal, 40, 658-661, 2005.

Lapin, M., Melo, M., Faško, P., and Pecho, J.: Snow cover changes scenarios for the Tatra Mountains in Slovakia, Proceedings of the 29th International Conference on Aplin Meteorology, 4-8 June 2007, Chambéry, Francúzsko, 2007.

Parajka, J. and Blöschl, G.: The value of MODIS snow cover data in validating and calibrating conceptual hydrologic models, J. Hydrol., 358, 240-258, 2008.

Parajka, J., Merz, R., and Blöschl, G.: Estimation of daily potential evapotranspiration for regional water balance modeling in Austria, Proceedings of the 11th International Poster Day and Institute of Hydrology, Bratislava, Slovak Academy of Sciences, 2003.

Parajka, J., Holko, L., Kostka, Z., and Blöschl, G.: MODIS snow cover mapping accuracy in a small mountain catchment - comparison between open and forest sites, Hydrol. Earth Syst. Sci., 16, 2365-2377, doi:10.5194/hess-16-2365-2012, 2012.

Pekárová, P. and Szolgay, J.: Scenarios of changes in selected components of the hydrosphere and biosphere in the Hron River Basin and the balance due to climate change, Veda Bratislava, Slovakia, 2005 (in Slovak).

Stocker, T. F., Qin, D., Plattner, G.-K., Tignor, M., Allen, S. K., Boschung, J., Nauels, A., Xia, Y., Bex, V., and Midgley, P. M. (Eds.): IPCC, 2013: Climate Change 2013: The Physical Science Basis. Contribution of Working Group I to the Fifth Assessment 
Report of the Intergovernmental Panel on Climate Change, Cambridge University Press, Cambridge, 2013.

Szolgay, J., Danáčová, M., Jurčák, S., and Spál, P.: Multilinear flood routing using empirical wave-speed discharge relationships: Case study on the Morava River, J. Hydrol. Hydromech., 56, 213-227, 2008.
Valent, P., Daneková, J., and Riverso, C.: Uncertainties in the HBV model calibration, Acta Hydrologica Slovaca, Vol. 12, No. 2, IH SAS, Bratislava, Slovakia, 2011 (in Slovak). 